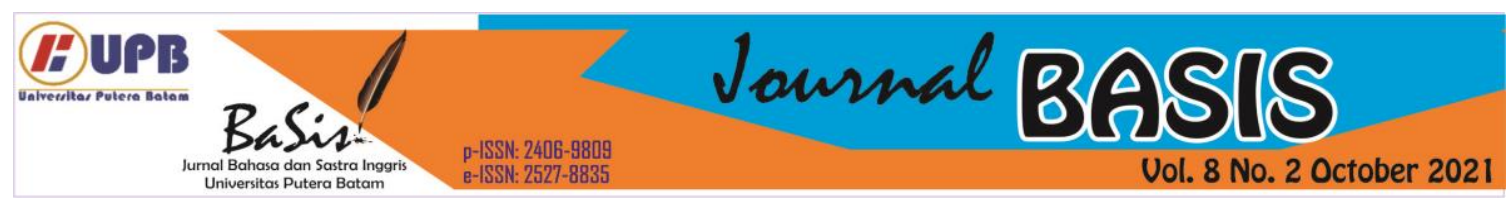

\title{
FLOATING IDENTITY REFLECTED IN ROBERT OLEN BUTLER'S SHORT STORY “CRICKET”
}

\author{
Harry Yoesoef Pabiona ${ }^{1}$ \\ Universitas Putera Batam, Batam, Indonesia \\ pb171210078@upbatam.ac.id \\ Tomi Arianto ${ }^{2}$ \\ Universitas Putera Batam, Batam, Indonesia \\ tomi.arianto@puterabatam.ac.id
}

\begin{abstract}
This research is aimed to analyze the floating identity from the main character, Ted, represented in Robert Olen Butler's short story titled "Cricket". Then, using postcolonialism approach, the identity of the main character, Ted, will be analyzed in relation to the occurrence of ambivalence and mimicry in the short story "Cricket." The method used to analyze the short story is by using descriptive qualitative method. The author seeks, describes, and analyzes the data. The data is taken from the narration and dialogue of the short story which is related to the research. The theory used in this research is the post-colonial theory from the post-colonial theory expert, Homi K. Bhabha. The occurrence and phenomena of hybridity in form of ambivalence and mimicry in the short story used to determine the main character's identity reflected in the story, based on Bhabha's definition of mentioned term. The results of this study show the existence of identity crisis in which the main character, Ted, couldn't sure which identity he belongs to. Ted has a "defective" identity where he accepted Western superiority but didn't let go his Eastern roots, trapped in his own dilemma in achieving his identity.

Keywords: Floating Identity, hybridity, Cricket Story
\end{abstract}

\section{INTRODUCTION}

Humanity has experienced a turbulence era in the past century. Two world wars happened, and the subsequent decolonization and the Cold War that follows after creating an after effect which changed the world forever. The influence of the colonizer's culture and way of life have affected the customs of the colonized people and their world, thus creating a new crossculture "identity". However, this newformed identity cannot be considered as a "true identity" and they will never be. The foundation between one identity and another is fundamentally different, which is also the main point of the postcolonial studies. According to
Huntington in Ashcroft (2002), postcolonial is a theory that assumes and simultaneously explores the fundamental differences between colonial and colonizer in addressing the direction of their cultural development. As such, this new identity eventually cause the subject (people) to wonder who he or she really is, where they belong to, or where should they belong. These thoughts eventually culminating in the difficulties which the subject experienced in order to understand their position or role, or in other words, their "identities" in this world.

The post-colonial theory is applied to study the culture of a third world 
country, or an ex-colonized country which has been subjected in the colonialism era. The term 'postcolonialism' is originally adapted by historians after World War II for an era which states around the world gained independence and released their status as a "colonized country." Postcolonialism studies for years have proven that there is a certain "resistance" from the colonized to the colonizer, or more specifically, from ex-colonized culture to reject some or part of its colonizer culture and social structure such as Western culture. However, the opposite also held true, where the colonizer rejected the colonized culture because they deemed it as inferior, or in other words, does not conform to the "superior" manners or ways that the Western have been thought to. One of the well-known examples is what Spivak (1988) called the "sub-altern."

When the era of colonization is mostly over in the aftermath of World War II, its hundred years history leaves many impacts to the colonized world, or more specifically, between the colonized people and its colonizer. After that, there were events like colonization in terms of an occupier influencing the natives, similar to colonization. While the objectives and motives are different, they also have the same effect as the post-colonialism described (for example, North Korea and South Korea divide). Talking about colonialism is not just talking about dominion, trade, power, and resources, but also about culture and society. In those terms, there is a little similarity between the colonized and the colonizer, if it is not entirely different at all. In history, some people even fight their colonizer just because they reject the colonizer's culture entirely or some part of it. However, as colonialism entered its final era, many people would integrate with the colonizer's culture. They have been given education, position, or job. The resulting effect is that some of the colonized learn the colonizer's culture, society, and their way of life. Its legacy survived and still affects all ex-colonized society in the world and after some years, garner more interest from the academic communities to study this field, even when the era of colonialization is over.

The post-colonialism study gained more interest in the late of 1970 s with texts such as Orientalism by Edward Said and let to the creation and development of the colonial discourse theory, based from work of critics such as Homi K. Bhabha. However, the term 'post-colonial' or 'post-colonialism' itself was not used to describe these kinds of studies which is related to colonial discourse. As stated by Spivak in Ashcroft (2002), for example, he first used the term 'post-colonial' in the collection of interviews and recollections published in 1990 called The Post-Colonial Critic. Ashcroft (2002) also stated that although the study of the effects of colonial representation influenced the work of these critics, the term 'post-colonial' was first used to refer to cultural interactions within colonial societies in literary circles. The term has been widely used to signify cultural experience of societies that were former European/Western colonies. The goal of post-colonial theory development is to combat the remnants of the impact of colonialism on culture. It just not concerns about the preservation of the old ways or the past world, but also to learn on how the world can move together from the colonial era towards a mutual respect in between the cultures in the future. 


\section{LITERATURE REVIEW}

According to Ashcroft (2002), the meaning and the scope of 'postcolonialism/post-colonialism' is now becomes wider. It became including the study and analysis of territorial conquests. Furthermore, later studies include the various events of colonialisms, the operations of an empire, the subject construction in colonial discourse and the resistance of those subjects, and most importantly perhaps the difference of responses between them and their contemporary colonial legacies in both pre-and postindependence countries. While its use has tended to focus on the cultural production, it is becoming widely used in historical, political, social, economic analyses, as these factors continue to engage with the impact of colonialism upon the society of the world.

\subsection{Hybridity}

Hybridity in post-colonial terms is a fusion new culture created by the existence of colonialism, in particular between the colonizers and the colonized (Ashcroft, 2002). The term refers to the mixing of two cultures to create a new, third form, namely "hybrid" culture. The term "hybridity" is related to Homi $\mathrm{K}$. Bhabha's work which analyzes the relationship of the colonizers and the colonized, especially their dependence on each other and the mutual construction of their subjectivity. The idea of hybridity also underlies other attempts to put an importance of the mutuality of cultures.

According to Furqon (2020), hybridity stemmed and ended from an effort to search an identity. As new countries emerged from colonialism and gained their independence, these countries would struggle to seek its own unique identities, in particular its own people. After a period of process, finally those countries would find their own identities. The process will involve the whole concept of Homi K. Bhabha's theory of hybridity. According to Bhabha in Furqon (2020), the culture relationship between the colonizers and the colonized is always inside of what Bhabha called the concept of liminal space, the place where both of the culture could interact each other. The result of the cultural interaction is constructed inside what Bhabha called "The Third Space of Enunciation."

\subsection{Ambivalence}

Ambivalence is a part of hybridity concept. According to Ashcroft (2002), the term ambivalence first appeared in psychoanalysis discipline to describe a contradiction of thinking between desiring one particular thing while simultaneously wanting its opposite. Furthermore, according to Young in Ashcroft (2002), ambivalence can also be referred as a simultaneous attraction toward and repulsion from an object, person, or action. Later, Homi K. Bhabha adapted the idea into the colonial discourse theory. In it, it describes the complex mix of attraction and repulsion that characterizes the relationship between the colonizers and colonized (Bhabha, 1984).

Ashcroft (2002) stated that a cultural relationship is called ambivalent when a colonized person/people is not fully opposed to the colonizer's influence, as they maybe "accepting" or "compromising" some of the colonizer culture. Rather than a black-and-white definition which tells that some colonized subjects are in total compliant or resisting, ambivalence in colonial discourse theory suggests that the compliance and resistance exist in a fluctuating relation within the colonial subject. However, with an importance in Bhabha's theory, ambivalence 
symbolize a disturbance of total authority for colonial domination because it affects the relationship between colonizer and colonized (Bhabha, 1984).

Ambivalence is therefore an unwelcome aspect of colonial discourse for the colonizer (Ashcroft et al., 2002). The problem for colonial discourse is that it wants to produce totally compliant subjects who can replicate the colonizer's way of thinking and life. Instead it produces "ambivalent subjects" instead, whose mimicry is nothing more than an act of "mockery", in Bhabha's terms (Bhabha, 1984). Ambivalence describes this fluctuating relationship between mimicry and mockery, an ambivalence that is fundamentally unsettling to colonial dominance.

\subsection{Mimicry}

Mimicry is also a part of Bhabha's hybridity concept. It is also an important term in post-colonial theory because it also becomes a part to describe the ambivalent relationship between colonizer and colonized (Ashcroft et al., 2002). When a colonial discourse encourages the colonized subject to mimic the colonizer a by adopting the colonizer's way of thinking and life, the result is not as easy and fruitful as people might think. Instead, it resulted into a defective replication. It is also viewed as a form of mockery. As Western and Eastern culture are fundamentally different (although some certain part contains similar value and morals), ultimately there will be a different point of view of how they see a phenomenon or a problem. An Easterner may say that some attitudes are considered rude, but a Westerner may say that the attitude is particularly fine for them, or at least acceptable. This simple fact proves that no matter how a person tries to copy something from another, in this case between the colonized and the colonizer, they can't simply become one. Not to mention, the colonizer itself doesn't accept the colonized to become one of them. Because of this, usually there is a "barrier" set for the colonized in order not to reach the same level as the colonizer in terms of almost everything. Mimicry is also related to ambivalence as they both concern about how the effect of colonizer's culture affects the colonized when they tried to accept or to replicate some of their ways in culture.

\subsection{Previous Studies}

First study is conducted by Waworuntu \& Arianto in Hybridity of the Characters in My Son the Fanatic Story by Hanief Kureishi. The research aimed to find the forms of hybridity as a result of postcolonialism. She revealed the hybridity represented by the main characters, Parvez and Ali. The study used the post-colonialism approach in the hybridity concept of Homi K Bhabha. According to Bhabha (Waworuntu \& Arianto, 2010), hybridity is a cross between two interacted diverse cultures. In this case, hybridity is not only seen as a fusion of culture but also cultural products placed in social and historical space under post-colonialism which are part of the imposition of colonial power relations. The conclusion is that the characters in the story were "trapped" in their own "identity", a product from what has been explained as mockery related to mimicry, which is related to the hybridity itself. The difference between the study in this paper refers to the difference analysis of data source in relation to the short story.

Second study is conducted by Alfiah et. al. (2020) in Hibriditas, Mimikri, dan Ambivalensi dalam Novel 
Kirti Njunjung Drajat Karya $R . \quad T g$. Jasawidagda: Kajian Postkolonialisme. It aims to describe the form, occurrences, and alignment from the hybridity, mimicry, and ambivalence in Kirti Njunjung Drajat novel by $\mathrm{R}$. Tg .Jasawidagda. It used the postcolonialism approach and the hybridity concept of Homi K. Bhabha. The results of this study show the existence of a hybridity in a cultural relation, social, political and language. Mimicry form in a cultural relation, social, and mindset against the main character named Darba experience mimicry contrary to his family. Ambivalence form also found in to main character when Darba liked Westerners way of thinking, but Darba never left its Eastern roots. The research difference between the study and this paper is related to the difference of data source. This research uses a short story as a data source instead of a novel.

\section{RESEARCH METHOD}

This research used descriptive qualitative method. According to Taylor et. al. (2016), qualitative method is a research procedure that produce data in descriptive form, either from observable verbal or from written texts based from people and their behaviors. The phase of the research is divided by two stage. The first stage is the data collection stage. Data collection is a method which uses human senses in order to find findings and empirical facts related to the research itself. The next phase involves the analysis phase, meant the collected data which will be analyzed by the researcher. It is done after reading the short story titled Cricket by Robert Olen Butler. In the analysis phase, a qualitative method is used, which in accordance and related to the post-colonialism theory.

Every element in the short story "Cricket" is sorted and identified by looking for elements related to hybridity, ambivalence, and mimicry to the identity of Ted. Ted has a conflicting view about finding his "identity" as a person who belongs to a particular culture. Furthermore, the data analysis stage is done by a work system that contains a variety of relevant written sources in terms of definition and relevance to the study. The data used in the research include basic and supporting data. The main data in the form of short story entitled "Cricket" by Robert Butler, while the supporting data comes in the form of literature references and postcolonial theory.

\section{FINDINGS AND DISCUSSION}

The findings and discussion of this research is to show the hybridity in form of ambivalence, and mimicry which occurs in the short story. The form of those elements is presented by the two main characters of the story. The first is Ted, a Vietnamese immigrant. The second is Bill, Ted's son. The excerpts of the story are taken and used as the proof for them. First, the hybridity is shown in the story, on an earlier excerpt of the story:

I hear myself sometimes and I sound pretty bitter, I guess. But I don't let that out at the refinery, where I'm the best chemical engineer they've got and they even admit it once in a while. They're good-hearted people, really. I've done enough fighting in my life. I was eighteen when Saigon fell and I was only recently mustered into the Army, and when my unit dissolved and everybody ran, I stripped off my uniform and put on my civilian clothes again and I threw rocks at the North's tanks when they rolled through the streets. (Butler, 2015) 
The latter part of the excerpt explains about Ted's background when he was still in Vietnam, his homeland. It shows a hybridity symbolized by an ambivalence, where Ted unable to enter the American "circle." The ambivalence while provides the colonized a chance to "replicate" the colonizer's way of thinking, at the same time it also closed its opportunity for the colonizer to become one of the colonizers because they will never accept it. Based on the quote, relating the former part of the excerpt, it can be assumed that Ted had entered and finished a high-degree education in America, because it was impossible for an eighteen-year-old recruit suddenly having a great skill in chemical engineering if he had not studied it at college, let alone as a high school student.

However, from the former part of the excerpt, it can be understood that Ted felt he should be more appreciated of having good skills at chemical engineering by his peers. He even felt bitter by it, but he tried to suppress it because they were good people. It can be implied that his co-workers never appreciated Ted deservedly no matter how he tried (according to his opinion) because he was a Vietnamese. Moreover, the bitter feeling in US after Vietnam War still lingers even until this day. The fact that the name "Ted" was also given by them (as it was not his real name), it seemed that his peers just didn't like anything that is not "American", especially when Ted himself is an actual Vietnamese. This shows despite being settled and adapted to the American's way of life, Ted felt that he was never fully accepted as an American itself, creating the hybrid identity based from VietnameseAmerican cross-cultural. Next, another sign of ambivalence is shown by the next excerpt:
They call me Ted where I work and they've called me that for over a decade now and it still bothers me, though I'm not very happy about my real name being the same as the former President of the former Republic of Vietnam. (Butler, 2015) These people who work around me are good people and maybe they call me Ted because they want to think of me as one of them, though sometimes it bothers me that these men are so much bigger than me. (Butler, 2015)

As mentioned before, the name "Ted" was given by people. Even though he was reluctant to be called by it (as shown in the passage), Ted willingly accepted that name. In other words, Ted indirectly accepted "American" superiority over Vietnamese. Ted mentioned about his co-workers as good people twice and it can be assumed that the reason he accepted the American name was because he did not want to make them disappointed. After all, he worked at the same place as them. While the change the name itself may not be significant, but the act symbolized Ted acceptance to a part of American culture, which is the main point of this discussion. It can be assumed that Ted accepted a part of American culture in order to settle at his working place. Meaning, in order to be accepted, Ted had no choice but to use the "American" name which he hoped would make things easier for him, rather than cling in to his Vietnamese name. The next excerpts show the sign of mimicry in the story:

We ended up here in the flat bayou land of Louisiana, where there are rice paddies and where the water and the land are in the most delicate balance with each other, very much like the Mekong Delta, 
where I grew up. These people who work around me are good people and maybe they call me Ted because they want to think of me as one of them, though sometimes it bothers me that these men are so much bigger than me. I am the size of a woman in this country and these American men are all massive and they speak so slowly, even to one another, even though English is their native language. I've heard New Yorkers on television and I can speak as fast as they do. (Butler, 2015)

This passage shows that even though Ted had adapted and settled in the USA, he still reminded himself about his homeland. Being westernized, Ted still couldn't escape fron his Eastern identity. Ted considered himself to be an American, yet also identify himself as being Vietnamese, contradicting each other. Even though he lived in Louisiana, he still thinks himself still in Mekong Delta, as both places were looked similar too him. Nevertheless, Ted is never truly freed from his Vietnamese culture, no matter how deep he adapted to American culture. Another proof is also shown by the fact that Ted thought the American speaks too slow. However, it is because the fact that Vietnamese language in general was actually spoken quicker, in comparison, to English. Ted did not realize the fact that it was his Vietnamese roots which could make him speak "as fast as" the New Yorkers do, which ironically, they themselves probably one of people that could match the language speed of the Vietnamese. It shows even though he already learned US English for years, his way of speaking is still Vietnamese. Trying to adapt American culture, he ended up never adapted it as a whole and never left his Vietnamese roots, creating a new yet defective identity. Next, the sign of ambivalence is also shown his son, Bill, as shown by the excerpt below:

Sometimes I say good-bye to him in Vietnamese and he wrinkles his nose at me and says, "Aw, Pop," like I'd just cracked a corny joke. He doesn't speak Vietnamese at all and my wife says not to worry about that. He's an American. (Butler, 2015)

The point of the excerpt as can be seen for the quote is the fact that Ted tried to speak Vietnamese, intending to introduce the Eastern culture to his son, Bill. Here, it can be said that Ted doesn't want to let go his eastern roots. It is also implied that Ted actually worry about his son if his wife doesn't remind him to be worry. It shows the Ted's urgency and intention to keep his Vietnamese culture, even though he considered himself as a westernized person.

By analyzing all the hybridity from the story's excerpts it can be concluded that Ted experience what is called "floating identity" in the story. The identity of Ted in the story can be called "a defective one" in terms of postcolonial discourse. Ted doesn't know which identity he should belong. He doesn't want to lose his Eastern roots but at the same time recognizes the opportunity and the need to acknowledge the Western influence, leaving him with a unique identity that is neither wholly as a colonized nor a colonizer. It is reflected by the way he commented his past and present life in the story. It also can be said that he shows a form of resistance into something that he doesn't want to lose, which is his Eastern culture. It creates an inner struggle in the main character, 
Ted, leaving him unable to find his selfidentity.

\section{CONCLUSION}

The floating identity in the story was shown by the main character Ted using the characterization of Homi Bhabha's post-colonialism theory. The hybridity is shown by the ambivalence and mimicry between both characters. Ted has a defective identity as he acknowledge both of the colonized and the colonizer identity, wanting to keep the Western influence but doesn't want to lose his Eastern roots. It creates an inner struggle where Ted tried to find his own "true identity." It is showed by an ambivalence where Ted which feels that he is not fully accepted by American people as one of them even though he already settled there and learn their way of life for years. Another ambivalence is shown by Ted's acceptance of adopting his American nickname by his peers rather than using his original Vietnamese name in order to be accepted by his co-workers in his working place, mimicking them and acknowledging the superiority of the colonizer's influence.

The characteristics of mimicry is shown by Ted's false assumption about American's culture identity and his mockery of their way of speaking. No matter how long Ted tried to adopt the American culture, his Vietnamese roots will still remain. It is shown by his impaired assumption of how slow the American speak, while actually he was the one who speak too quick for American standard, thanks to his Vietnamese roots. However, even though he accepted it, he is also bothered by it, showing resistance. It shows a conflict of identity whether Ted stays on his Vietnamese roots, or the new American culture.

\section{REFERENCES}

Alfiah, Novtarianggi, G., \& Sulanjarai, B. (2020). Hibriditas , mimikri , dan ambivalensi dalam novel kirti njunjung. JISABDA, 2(1), 28. https://doi.org/doi:10.26877/jisabda .v2i1.6220

Ashcroft, B., Griffiths, G., \& Tiffin, H. (2002). Post-colonial studies: the key concepts. Choice Reviews Online, 39(06), 39-3153-39-3153. https://doi.org/10.5860/choice.393153

Bhabha, H. K. (1984). Of mimicry and man: The ambivalence of colonial discourse. Discipleship: A Special Issue on Psychoanalysis, 28, 125133.

https://doi.org/https://doi.org/10.23 07/778467

Butler, R. O. (2015). Cricket. A Good Scent from A Strange Mountain, 320.

Furqon, S., \& Busro, N. (2020). Hibriditas postkolinialisme homi k. bhabha dalam novel midnight's and children salman rushdie. JENTERA: Jurnal Kajian Sastra, 9(1), 73. https://doi.org/10.26499/jentera.v9i 1.494

Spivak, G. C. (1988). Can the subaltern speak. Die Philosophin, 14(27), 42-58.

https://doi.org/10.5840/philosophin 200314275

Taylor, S., Bogdan, R., \& DeVault, M. (2016). Introduction to qualitative research method (4th ed.). New Jersey: John Wiley \& Sons, Inc.

Waworuntu, M., \& Arianto, T. (2019). Hybridity of the characters in my son the fanatic. BASIS, 6(2), 197208.

https://doi.org/https://doi.org/10.33 884/basisupb.v6i2 